Original Research

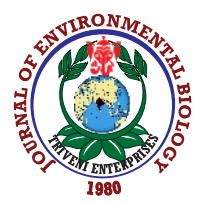

DOI : http://doi.org/10.22438/jeb/41/3/MRN-1266
Journal Home page : www.jeb.co.in ^ E-mail : editor@jeb.co.in

\title{
Characterization of a novel antifungal protein from Acacia senegal seeds
}

\author{
D.S. Solanki', S. Kumar', K. Parihar', A. Tak', P. Gehlot ${ }^{1 *}$, R. Pathak ${ }^{2}$ and S.K. Singh ${ }^{2}$ \\ 'Department of Botany, Jai Narain Vyas University, Jodhpur-342001, India \\ 'Division of Plant Improvement and Pest Management, ICAR-Central Arid Zone Research Institute, Jodhpur-342 003, India \\ *Corresponding Author Email : drpg73@rediffmail.com
}

\begin{abstract}
Aim : The aim of the present study was to isolate antifungal protein from seeds of Acacia senegal in order to develop a new, effective and environmental friendly biofungicide.

Methodology : Antifungal protein from A. senegal seeds was extracted and purified through ammonium sulphate precipitation, dialysis, ion exchange and gel filtration chromatography. The novel antifungal was characterized employing SDS-PAGE, chitinase activity and antifungal efficacy. The purified protein was also characterized through MALDI-TOF MS/MS.

Results : The yield of purified antifungal protein was estimated

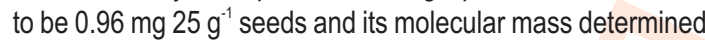
by SDS PAGE was $52.9 \mathrm{kDa}$. The purified protein exhibited antifungal activity against phytopathogenic fungi viz., Macrophomina phaseolina and Fusarium oxysporum also possessed chitinase activity. The purified protein was characterized through MALDI-TOF MS/MS and its spectra revealed 14 peptides with their specific amino acid sequences.

Interpretation : The antifungal protein isolated from $A$. senegal seeds has broad-spectrum antifungal activity with chitinase activity against pathogenic fungi that can be exploited for management of fungal disease as biopesticide to promote sustainable agriculture.

Key words: Acacia senegal, Antifungal protein, Chitinase activity, MALDI TOF-Mass spectroscopy, Phytopathogenic fungi

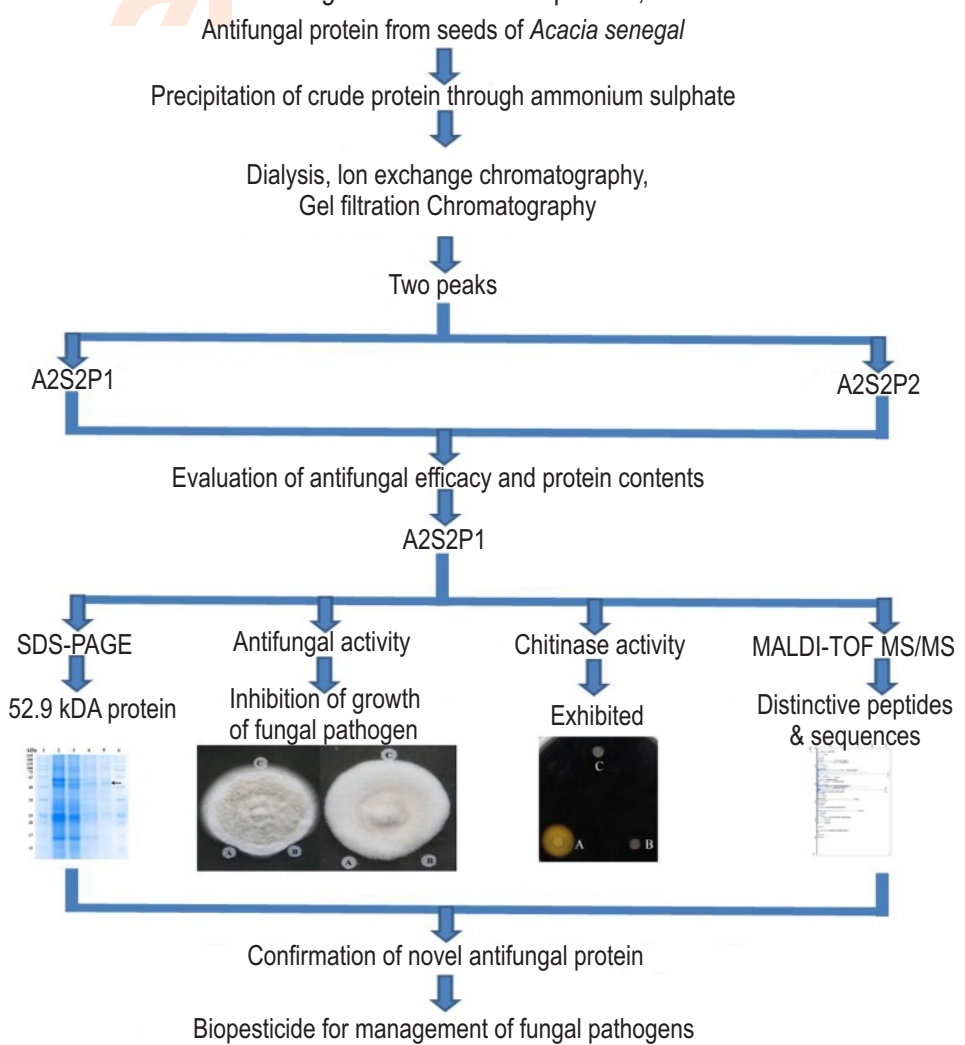

How to cite : Solanki, D.S., S. Kumar, K. Parihar, A. Tak, P. Gehlot, R. Pathak and S.K. Singh: Characterization of a novel antifungal protein from Acacia senegal seeds. J. Environ. Biol., 41, 607-612 (2020). 


\section{Introduction}

Plant growth, development, yield and quality are severely affected by insect pests and pathogenic microorganisms. Chemical insecticides and fungicides have been applied to control the menace in agriculture since centuries, but their adverse effect on human and soil health has compelled the researchers to think for alternates. Antifungal proteins are defense proteins produced by plants during fungal infection to protect plants from fungal pathogens by restricting or suppressing their growth, spread and provide resistance to fungal attack (Yan et al., 2015). In general, antifungal proteins are considered as biofungicides that have broad spectrum antifungal activity through several mechanisms such as inhibition of fungal cell wall synthesis, liberation of chitin oligosaccharides from cell wall, damage to cellular ribosomes, inhibition of DNA synthesis or cell cycle, disintegration of fungal membrane etc. (Klomklao et al., 2011).

Seed coat provides physical resistance against several pathogenic microorganisms in the soil, however, at germinating stage, plant defense strategy protects emerging seedlings from pathogenic organisms (Leubner-Metzger, 2003). Occurrence of antifungal proteins in seeds may play a vital role in shielding the seeds from harmful microorganisms during germination. These proteins participate in defense mechanisms against number of fungal pathogens (Ferreira et al., 2007). A number of antifungal proteins from legume seeds have been purified and characterized by researchers (Praxedes et al., 2011; Ajesh and Sreejith, 2014; Solanki et al., 2018a, 2018b) that can be used as biofungicide for sustainable management of plant diseases.

Only few studies have been conducted on isolation and characterization of antifungal protein from seeds of native legumes plants of arid and semi arid areas of Thar Desert. This region has several indigenous leguminous tree species, including Acacia senegal that are well adapted to arid environment of western Rajasthan and are potential to restore soil fertility and sand dune stabilization (Jindal et al., 2011). It is a drought tolerant multipurpose leguminous tree species and an important forest resource for edible gum, food, wood and animal fodder (Wekesa et al., 2010).

Macrophomina phaseolina and Fusarium oxysporum have a very wide host range and causes huge losses in agricultural crops in western Rajasthan (Gautam et al., 2014, 2016). Plant antifungal proteins are peptides with diverse amino acid compositions and structures. They generally display rapid killing and broad-spectrum antifungal activities. Hence, antifungal proteins have high potential for therapeutic use, application in agriculture and can be used as natural fungicide for biocontrol of pathogenic fungi and providing protection to plants against diseases. Therefore, the present investigation is aimed at isolating antifungal proteins from seeds of native legume, $A$. senegal to develop eco-friendly biofungicide.

\section{Materials and Methods}

Extraction of crude protein: The pods were collected from $A$. senegal trees growing in the vicinity of Jodhpur, Rajasthan. Pods were dehulled and seeds were separated. Twenty-five gram seeds were soaked in distilled water for $24 \mathrm{hr}$ and homogenized in $100 \mathrm{ml}$ of $25 \mathrm{mM}$ Tris- $\mathrm{HCl}$ buffer $(\mathrm{pH}$ 7.2). The resultant homogenate was centrifuged at $10,000 \mathrm{rpm}$ for $20 \mathrm{~min}$ at $4^{\circ} \mathrm{C}$ for separating seed debris. The clear supernatant was designated as crude protein. It was evaluated for crude protein content and antifungal efficacy.

Ammonium sulphate precipitation of crude protein: The crude protein extract was saturated and precipitated by adding ammonium sulphate @ 30\%,60\% and 90\% (w/v) successively to precipitate protein fraction as suggested by Klomklao et al. (2011). After each precipitation, protein fraction was separated through centrifugation at $10000 \mathrm{~g}$ for $15 \mathrm{~min}$ at $4{ }^{\circ} \mathrm{C}$ and designated as $A 1, A 2$ and $A 3$, respectively. All three fractions $A 1$ (0-30\%), A2 $(31-60 \%)$ and $A 3(61-90 \%)$ were preliminary screened for their protein content and antifungal efficacy.

Dialysis: The precipitated protein fraction exhibiting antifungal activities was dialysed by mixing with $25 \mathrm{mM}$ Tris-HCl buffer in distilled water to eliminate ammonium sulphate molecules, undesired organic molecules and other impurities by following the methodology of Reed et al. (2007).

Ion exchange chromatography: The dialysed protein fraction exhibiting antifungal activity was again purified by ion exchange chromatography using activated di ethyl amino ethyl (DEAE) cellulose as chromatography media packed in glass column of $1 \times 15 \mathrm{~cm}$ dimension. The DEAE column was run with $25 \mathrm{mM}$ Tris- $\mathrm{HCl}$ buffer maintaining run rate of $0.5 \mathrm{ml} \mathrm{min}^{-1}$ and fractions of $3 \mathrm{ml}$ were harvested individually and their optical density was measured at $280 \mathrm{~nm}$ using UV-spectrophotometer. To elute bound protein, $25 \mathrm{mM}$ Tris- $\mathrm{HCl}$ buffer $(\mathrm{pH} 7.2)$ containing $1 \mathrm{M}$ $\mathrm{NaCl}$ was poured in the column maintaining the same flow rate. The bound column fractions were collected separately and their absorbance was read at $280 \mathrm{~nm}$. An ion exchange chromatogram was drawn separately between collected unbound and bound fractions. The maximum absorbance peak in chromatogram was named as A2S1 for unbound fraction and A2S2 for bound fractions, which were taken for further characterization of antifungal efficacy and protein contents.

Gel filtration chromatography: The DEAE fraction (A2S2 protein) that showed antifungal efficacy was again purified by gel filtration chromatography using Sephadex G-75 media packed in glass column of $1 \times 30 \mathrm{~cm}$. The column was gently loaded with protein fraction (A2S2) and run with $20 \mathrm{mM}$ Tris- $\mathrm{HCl}$ buffer at a run rate of $1 \mathrm{ml} \mathrm{min}^{-1}$ filtration to elute fractions of $3 \mathrm{ml}$ each. The optical density of eluted fractions were recorded at $280 \mathrm{~nm}$. The gel filtration chromatogram yielded two major peaks A2S2P1 and $\mathrm{A} 2 \mathrm{~S} 2 \mathrm{P} 2$. Both protein fractions (A2S2P1 and A2S2P2) were evaluated for their antifungal efficacy and protein contents.

Sodium dodecyl sulphate-polyacrylamide gel electrophoresis (SDS-PAGE): To determine the purity of protein and its molecular mass, SDS-PAGE was carried out. The protein fraction exhibiting antifungal activity along with protein molecular mass marker (Thermo fisher Bioscience, USA) was run on $0.75 \mathrm{~mm}$ thick gels containing $12 \%$ gradient of acrylamide with a staking gel of $5 \%$ acrylamide in the Laemmli system (Laemmli, 1970). Coomassie 
brilliant blue dye was used for staining of gel.

Protein estimation: Protein content of different purified fractions i.e., crude protein, ammonium sulphate fraction, ion exchange fraction and gel filtration fraction were estimated by the method of Bradford (1976) by plotting graph of purified fractions vis-à-vis bovine serumalbumin as standard protein using Commassie blue dye.

Antifungal activity of protein fractions: In-vitro antifungal activity was carried out using the disc diffusion method by a radial growth inhibition assay as per the method described by Bauer et al. (1966). Different fractions of protein isolated at various stages, i.e., crude protein, ammonium sulphate fractions, ion exchanger column fractions and gel filtration fractions were evaluated for their antifungal efficacy against molecularly identified pathogenic fungi namely, M. phaseolina (JQ954874) isolated from clusterbean roots and F. oxysporum (MF166767) from cumin roots. The pathogenic fungal isolates were first grown in Petri plates containing potato dextrose agar (PDA) for $48 \mathrm{hr}$ in a BOD incubator and then sterile circular paper disks of $0.5 \mathrm{~cm}$ diameter were placed $1 \mathrm{~cm}$ away from the young growing fungal mycelium colony margins. A $10 \mu$ laliquot of protein fraction was poured on to disks and then incubated at $25^{\circ} \mathrm{C}$ until the colony mycelia grew and interacted with peripheral disks (crescents of inhibition). Concurrently, paper disc poured with $10 \mu \mathrm{l}$ Tris- $\mathrm{HCl}$ buffer were used as control.

Chitinase activity: Sterile paper discs soaked in $10 \mu$ l of purified gel filtration protein fraction (A2S2P1 and A2S2P2) were placed on $1 \%$ chitin agar medium to detect chitinase activity. Paper discs soaked in extraction buffer were used as control. After inoculation at $25^{\circ} \mathrm{C}$ for $48 \mathrm{hr}$, chitin agar plate was stained with $2 \%$ iodine solution. The development of clear zone around the discs was observed (Kim et al., 2003).

MALDI-TOF MS/MS analysis: Purified single monomer antifungal protein band in SDS PAGE was identified and excised from gel, eluted and washed with $30 \mathrm{mM}$ potassium ferricyanide and $100 \mathrm{mM}$ sodium thiosulfate at ambient temperatures for 20 min. De-stained protein was digested with trypsin solution and mixed with matrix solution of a-Cyano-4-hydroxycinnamic acid in $0.1 \%$ trifluoroacetic acid $30 \%$ (v/v) and acetonitrile (1:2) (Agrawal et al., 2016). The extracted peptides were then subjected to Matrix Assisted Laser Desorption Ionization-Time of Flight Mass Spectroscopy/Mass Spectroscopy (MALDI-TOF MS/MS) analysis (UltrafleXtreme TM mass spectrometer) and spectra were obtained in $500-3,500 \mathrm{~m} / \mathrm{z}$ range using Bio Tools 3.0 software. The data obtained from mass spectroscopy were analysed employing mascot search program.

\section{Results and Discussion}

Although plants are exposed to high number of pathogens and do not possess immune system to defend against all the pathogens, but they have acquired defense mechanisms to fight against pathogenic microbes by producing a variety of proteins. These proteins are responsible for developing resistance against pathogens. Several studies have reported characterization of novel antifungal proteins from plants such as mungin (Ye and $\mathrm{Ng}, 2000$ ), dolichin (Ye et al., 2000a), sativin (Ye et al., 2000b), cowpea chitinase (Ye et al., 2000c) and French bean thaumatin-like protein (Ye et al., 1999). In the present study, efforts were made to isolate and characterize antifungal protein from seeds of $A$. senegal. Total crude protein extracted from seeds of $A$. senegal using Tris- $\mathrm{HCl}$ buffer was quantified as

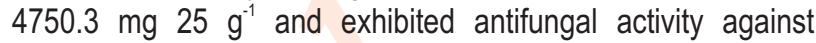
pathogenic fungi viz., M. phaseolina and F. oxysporum. The crude extract of protein was further precipitated with ammonium sulphate (w/v) at three level $0-30 \%, 31-60 \%$ and $61-90 \%$ resulted into $A 1, A 2$ and $A 3$ fractions, respectively. Ammonium sulphate precipitation of crude protein from other leguminous plant species Sesbania virgata (Praxedes et al., 2011), Vigna radiata (Solanki et al., 2018a) and Prosopis cineraria (Solanki et al., 2018b) has also been employed for separating seed protein. Each fraction tested for protein content and antifungal efficacy against pathogenic fungi revealed that the fraction $A 2$ exhibited antifungal properties. Fraction $\mathrm{A} 1$ and $\mathrm{A} 3 \mathrm{did}$ not inhibit the fungal growth and were, therefore discarded. Fraction A2

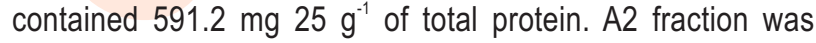
dialyzed to remove residues of ammonium sulphate salt which resulted in significant amount of pure dialyzed protein.

Dialyzed protein was subjected to ion exchange chromatography for further purification of protein into two fractions, i.e., unbound fraction (A2S1) and bound fraction (A2S2) (Fig.1a). Both protein fractions were again quantified for protein content and antifungal activity. A2S1 fraction failed to inhibit the growth of tested pathogenic fungi and was, therefore discarded,

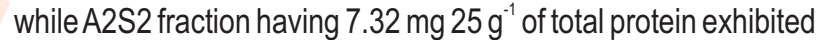
antifungal activity towards tested pathogenic fungi (M. phaseolina and F. oxysporum). Ajesh and Sreejiit (2014) also used dialysis and ion exchange chromatography for isolation of a novel antifungal protein from seeds of Clitoria ternatea.

Protein fraction A2S2 exhibiting antifungal activities were additionally purified by gel filtration chromatography. A2S2 fraction upon gel filtration yielded two peaks viz., major peak (A2S2P1 fraction) and minor peak (A2S2P2 fraction) (Fig. 1b). Gel filtration on Sephadex-75 using Tri- $\mathrm{HCl}$ buffer has also been used previously (Lin and Ng, 2008; Praxedes et al., 2011). A2S2P1 fraction contained $0.96 \mathrm{mg} 25 \mathrm{~g}^{-1}$ of total protein and exhibited in-vitro antifungal activity, while A2S2P2 fraction did not show anti-fungal activity against pathogenic fungi and was also discarded. We recorded $3.2 \mu \mathrm{g} 10 \mu \mathrm{I}^{-1}$ purified protein having highly effective capacity in controlling the mycelial growth of tested pathogenic fungi. SDS-PAGE characterization of A2S2P1 fraction revealed a single monomeric band of $52.9 \mathrm{kDA}$ molecular mass (Fig. 2). The isolated A2S2P1 purified protein showed positive chitinase activity on colloidal chitin agar plates (Fig. 3). The mode of action of isolated protein against pathogenic fungi tested is attributed to the fact that chitinase hydrolyzes $\beta, 1-4$ linkages between $\mathrm{N}$-acetylglucosamine residues of fungal cell 

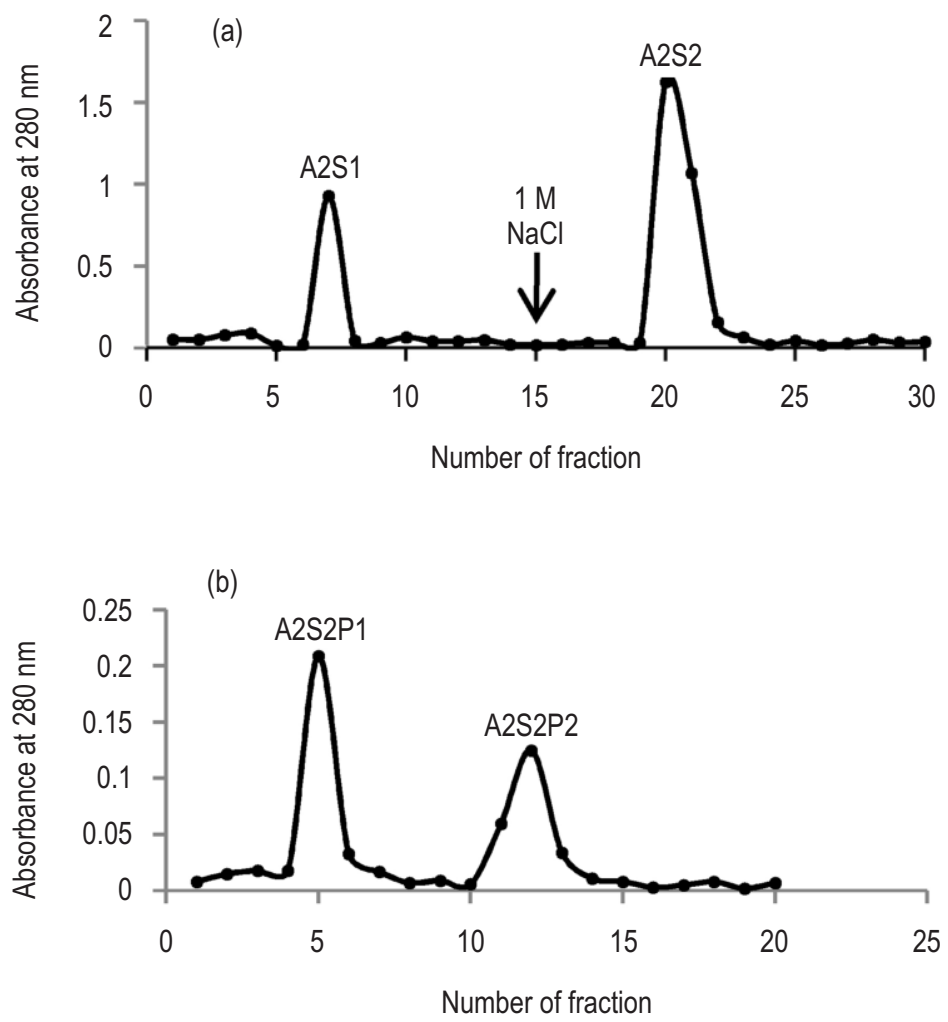

Fig. 1: (a) lon exchange chromatogram of ammonium sulphate precipitates fraction and (b) Gel filtration chromatogram of A2S2 fraction.

wall chitin and work as an antifungal protein by reducing the mechanical strength of fungal cell wall, and eventually destroying the pathogenic fungi through lysis (Yan et al., 2015).

The isolated and purified antifungal protein of $52.9 \mathrm{kDa}$ under present study is a novel protein as it is different from previously reported antifungal protein and peptides with molecular masses ranging from 5 to $67 \mathrm{kDa}$ isolated from legume seeds (Ye et al., 2000a, 2001; Ye and Ng, 2002a, 2002b; Wang et al., 2005; Park et al., 2009). Earlier two antifungal proteins from Acacia species viz., A. confuse ( $32 \mathrm{kDA})$ and $A$. plumose $(20 \mathrm{kDa})$ have been reported (Lopes et al., 2009; Lam and Ng, 2010). The novel antifungal protein under present study exhibited significant antifungal activity against M. phaseolina and F. oxysporum. Lam and $\mathrm{Ng}(2010)$ isolated chitinase like antifungal protein from $A$. confusa and demonstrated antifungal activity against Rhizoctonia solani, but there was no antifungal activity towards $F$. oxysporum indicating that antifungal proteins are species and race specific in nature (Ferreira et al., 2007; Klomklao et al., 2011). MALDI-TOF MS/MS characterization of purified antifungal protein (A2S2P1) revealed distinctive peptides fingerprints spectra with specific amino acid sequences according to their molecular mass ions (M/z) (Fig.4) are being reported for the first time from seeds of $A$. senegal. Earlier, this technique has been employed for characterization of antifungal seed protein in Prosopis

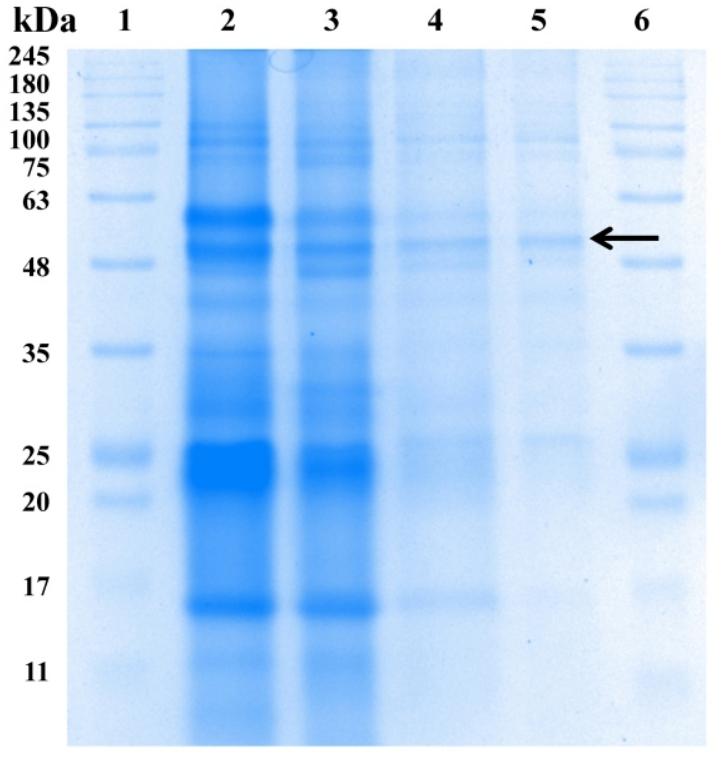

Fig. 2: SDS-PAGE of isolated fractions: column 1 and 6; molecular marker, column 2; Crude Protein, column 3; 31-60\% ammonium sulphate fraction (A2), column 4; lon exchange fraction (A2S2); column 5; Gel filtration fraction (A2S2P1). 


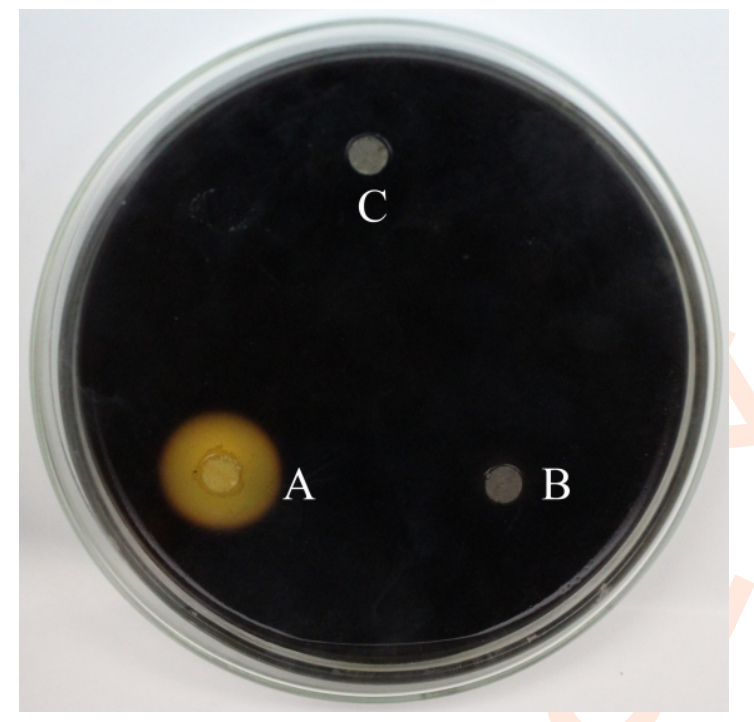

Fig. 3: Chitinase activity on colloidal chitin agar media of gel filtration chromatography fraction : (A)A2S2P1fraction; (B)A2S2P2 fraction and (C) control.

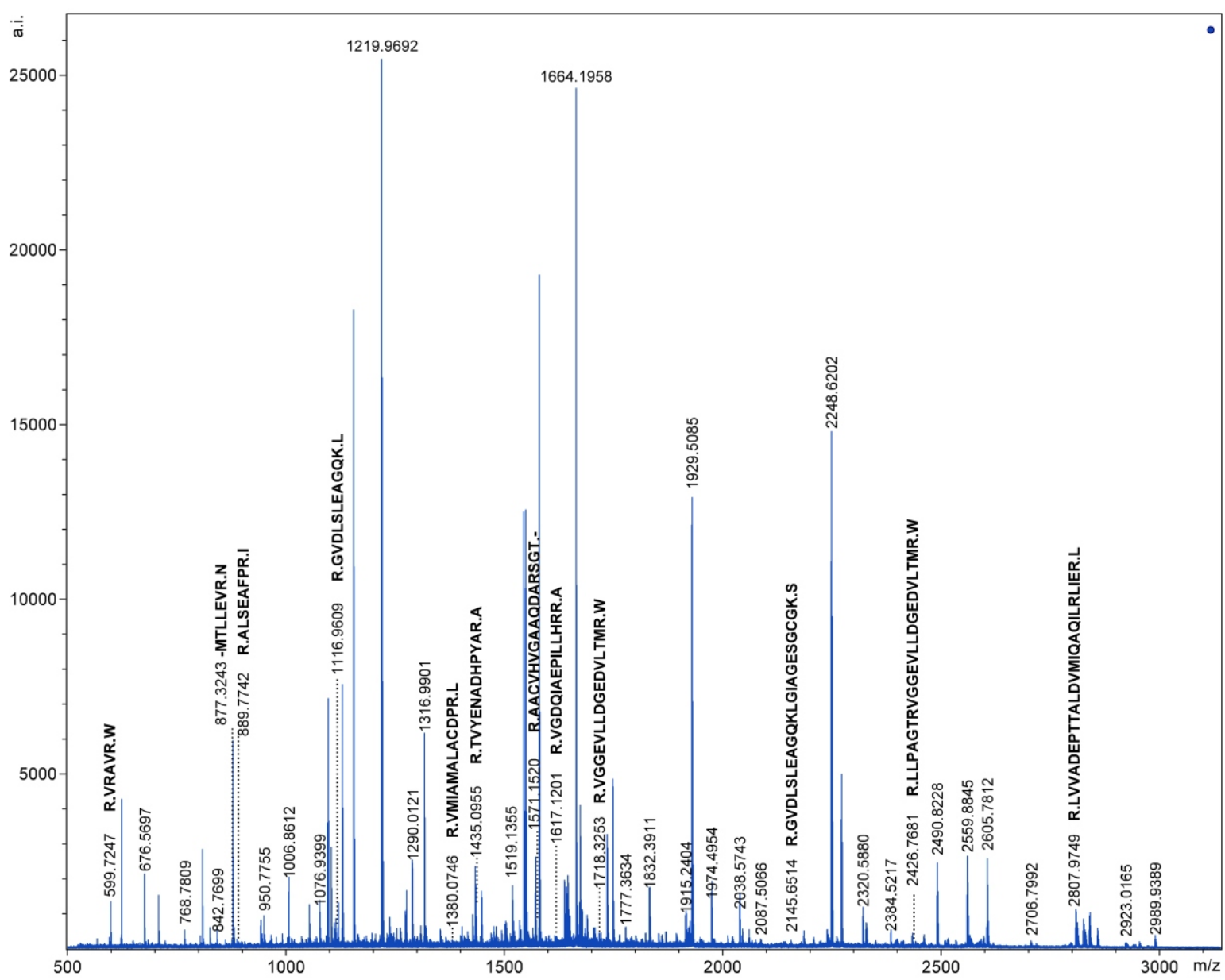

Fig. 4: MALDI -TOF MS/MS spectra of purified antifungal proteinA2S2P1. 
cineraria (Solanki et al., 2018b). It is concluded that the novel protein of $52.9 \mathrm{kDa}$ characterized from $A$. senegal seeds have distinctive peptides which exhibited antifungal activity against important plant pathogenic fungi. This protein can be used to develop a new, effective and environmental friendly biofungicide.

\section{Acknowledgment}

Corresponding author acknowledge the University Grants Commission, India for financial assistance (UGC-SAP-IICAS-I; F.5-1/2013[SAP-II]).

\section{References}

Agrawal, H., R. Joshi and M. Gupta: Isolation, purification and characterization of antioxidative peptide of pearl millet (Pennisetum glaucum) protein hydrolysate. Food Chem., 204, 365-372 (2016).

Ajesh, K. and K. Sreejith: A novel antifungal protein with lysozyme-like activity from seeds of Clitoria ternatea. Appl. Biochem. Biotechnol. 173, 682-693 (2014).

Bauer, A.W., W.M. Kirby, J.C. Sherris and M. Turck: Antibiotic susceptibility testing by a standardized single disk method. Am. J. Clin. Pathol., 45, 493-496 (1966).

Bradford, M.M.: A rapid and sensitive method for the quantitation of microgram quantities of protein utilizing the principle of protein-dye binding. Anal. Biochem., 72, 248-254 (1976).

Ferreira, R.B., S. Monteiro, R. Freitas, C.N. Santos, Z. Chen, L.M. Batista, J. Duarte, A. Borges and A.R. Teixeira: The role of plant defence proteins in fungal pathogenesis. Mol. Plant Pathol., 8, 677-700 (2007).

Gautam, R., S.K. Singh and V. Sharma: RAPD and nuclear rDNA ITS polymorphism within Macrophomina phaseolina isolated from arid legumes of Western Rajasthan. Proc. Natl. Acad. Sci., India, Sect. BBiol. Sci., 84, 171-181 (2014).

Gautam, R., S.K. Singh and V. Sharma: Molecular diagnosis and intraspecific genetic variability of root pathogens of arid legumes in Western Rajasthan, India. Rev. Biol. Trop., 64, 1505-1518 (2016).

Jindal, S.K., A. Tak, S.K. Singh, A. Pancholy, R. Pathak and A. Raturi: Molecular assessment of genetic diversity in Acacia senegal. Indian J. Agr. Sci., 81, 695-699 (2011).

Kim, K.J., Y.J. Yang and J.G. Kim: Purification and characterization of chitinase from Streptomyces sp. M-20. J. Biochem. Mol. Biol., 36, 185-189 (2003).

Klomklao, S., S. Benjakul, H. Kishimura and M. Chaijan: Extraction, purification and properties of trypsin inhibitor from Thai mung bean (Vigna radiata (L.) R. Wilczek). Food Chem., 129, 1348-1354 (2011).

Laemmli, U.K.: Cleavage of structural proteins during the assembly of the head of bacteriophage T4. Nature, 227, 680-685 (1970).

Lam, S.K. and T.B. Ng: Acaconin, a chitinase-like antifungal protein with cytotoxic and anti-HIV ${ }^{-1}$ reverse transcriptase activities from Acacia confusa seeds. Acta Biochim. Pol., 57, 299-304 (2010).

Leubner-Metzger, G.: Functions and regulation of $\beta$-1, 3-glucanases during seed germination, dormancy release and after-ripening. Seed Sci. Res., 13, 17-34 (2003).

Lin, P. and T.B. Ng: A novel and exploitable antifungal peptide from kale
(Brassica alboglabra) seeds. Peptides, 29, 1664-1671 (2008).

Lopes, J.L.S., N.F. Valadares, D.I. Moraes, J.C. Rosa, H.S.S. Araújo and L.M. Beltramini: Physico-chemical and antifungal properties of protease inhibitors from Acacia plumosa. Phytochemistry, 70, 871$879(2009)$

Park, S.C., J.Y. Kim, J.-K. Lee, I. Hwang, H. Cheong, J.W. Nah, K.S. Hahm and Y. Park: Antifungal mechanism of a novel antifungal protein from pumpkin rinds against various fungal pathogens. J. Agric. Food Chem., 57, 9299-9304 (2009).

Praxedes, P.G., J.K. Zerlin, L.O. Dias and R.A.B. Pessoni: A novel antifungal protein from seeds of Sesbania virgata (Cav.) Pers. (Leguminosae-Faboideae). Braz. J. Biol., 71, 687-692 (2011).

Reed, R., D. Holmes, J. Weyers and A. Jones: Practical skills in biomolecular sciences. $3^{\text {rd }}$ Edn., Pearson Education (2007).

Solanki, D.S., S. Kumar, K. Parihar, K. Sharma, P. Gehlot, S.K. Singh and R. Pathak: Purification and characterization of a novel thermostable antifungal protein with chitinase activity from mung bean. J. Environ. Biol., 39, 406-412 (2018a).

Solanki, D.S., S. Kumar, K. Parihar, A. Tak, P. Gehlot, R. Pathak and S.K. Singh: Characterization of a novel seed protein of Prosopis cineraria showing antifungal activity. Int. J. Biol. Macromol., 116, 16-22 (2018b).

Wang, S., J. Wu, P. Rao, T.B. Ng and X. Ye: A chitinase with antifungal activity from the mung bean. Protein Expr. Purif., 40, 230-236 (2005).

Wekesa, C., P.M. Makenzi, B.N. Chikamai, A.M. Luvanda and M.O. Muga: Traditional ecological knowledge associated with Acacia senegal (Gum arabic tree) management and gum arabic production in Northern Kenya. The International Forestry Review, 12, 240-246 (2010)

Yan, J., S.S. Yuan, L.L. Jiang, X.J. Ye, T.B. Ng and Z.J. Wu: Plant antifungal proteins and their applications in agriculture. Appl. Microbiol. Biotechnol., 99, 4961-4981 (2015).

Ye, X.Y. and T.B. Ng: Mungin, a novel cyclophilin-like antifungal protein from the mung bean. Biochem. Biophys. Res. Commun., 273, $1111-1115(2000)$.

Ye, X.Y. and T.B. Ng: Delandin, a chitinase-like protein with antifungal, HIV-1 reverse transcriptase inhibitory and mitogenic activities from the rice bean Delandia umbellata. Protein Expr. Purif., 24, 524-529 (2002a).

Ye, X.Y. and T.B. Ng: A new antifungal protein and a chitinase with prominent macrophage-stimulating activity from seeds of Phaseolus vulgaris cv. pinto. Biochem. Biophys. Res. Commun., 290, 813-819 (2002b).

Ye, X.Y., T.B. Ng, P.W. Tsang and J. Wang: Isolation of a homodimeric lectin with antifungal and antiviral activities from red kidney bean (Phaseolus vulgaris) seeds. J. Protein Chem. 20,367-375 (2001).

Ye, X.Y., H.X. Wang and T.B. Ng: First chromatographic isolation of an antifungal thaumatin-like protein from French bean legumes and demonstration of its antifungal activity. Biochem. Biophys. Res. Commun., 263, 130-134 (1999).

Ye, X.Y., H.X. Wang and T.B. Ng: Dolichin, a new chitinase-like antifungal protein isolated from field beans (Dolichos lablab). Biochem. Biophys. Res. Commun., 269, 155-159 (2000a).

Ye, X.Y., H.X. Wang and T.B. Ng: Sativin: Anovel antifungal miraculin-like protein isolated from legumes of the sugar snap Pisum sativum var. macrocarpon. Life Sci., 67, 775-781 (2000b).

Ye, X.Y., H.X. Wang and T.B. Ng: Structurally dissimilar proteins with antiviral and antifungal potency from cowpea (Vigna unguiculata) seeds. Life Sci., 67, 3199-3207 (2000c). 